OSLa $\begin{aligned} & \text { Binyam Sisay Mendisu \& Janne Bondi Johannessen (eds.) Multilingual Ethiopia: Linguistic Chal- } \\ & \text { lenges and Capacity Building Efforts, Oslo Studies in Language 8(1), 2016. 219-242. (ISSN 1890- } \\ & \text { 9639) }\end{aligned}$
http://www. journals.uio.no/osla

\title{
ON THE ROLE OF SOUTH ARABIAN AND \\ ETHIO-SEMITIC WITHIN A COMPARATIVE \\ SEMITIC LEXICOGRAPHICAL PROJECT
}

LUTZ EDZARD

\section{ABSTRACT}

Genetic classification in general depends to a large extent on the criteria selected. Inspired by Kogan 2015 and other sources, this paper looks at specific lexical peculiarities and semantic traits in the South Semitic (mainly modern South Arabian and Ethio-Semitic) lexicon, in order to determine the value of the South Semitic lexicon for genetic classification within Semitic at large.

\section{[1] INTRODUCTION}

This paper focuses on the role and importance of the lexicon for genetic classification, more specifically on the role of (mainly modern) South Arabian and Ethio-Semitic in this context, a role which recently has been highlighted by Kogan (2015). It is a truism that linguistic classification to a large degree depends on the criteria selected, i.e. phonological, morphological, and other data. Therefore, the main criteria, or rather shared innovations that are usually cited in this connection, are summarized in the following (cf. Faber 1997: 7-12):

- East Semitic is characterized by the development of an adjectival ending -üt (pl. m.) and by the dative suffixes -kum and -šum;

- West Semitic is characterized by the suffix conjugation denoting past tense (as opposed to the Akkadian stative) and a prohibitive negator 'al;

- Central Semitic is characterized by a series of pharyngealized consonants, a prefix conjugation for nonpast without gemination of the second root consonant and the leveling of prefix vowels in this conjugation, the generalization of a -t- suffix (as opposed to - $k$-) in the suffix conjugation, and the development of a compound negative marker *bal; the Northwest Semitic part of Central Semitic (as being distinct from Arabic) is characterized by the change of word-initial $w$ to $y$ (except for the con- 
junction $w^{-}$) and a doubly marked plural (internal and external); further internal isoglosses apply;

- South Semitic is characterized by the generalization of a $-k$ - suffix (as opposed to - $t$ - above) in the suffix conjugation and by the generalization of (')al as a verbal negator; Eastern South Semitic (Modern South Arabian), as opposed to Western South Semitic (old South Arabian and EthioSemitic) features a pre-fixed definite article $C(a)$, with $C$ being one of the gutturals', h, or $h$.

Goldenberg (2013: 45f.) lists the following further classification criteria:

- the distribution of the intraflexion ("broken plural") in Arabic, SouthArabian, and Ethio-Semitic;

- internal vowel lengthening in the binyanim (forms III and VI in Arabic);

- consistent use of - $a$ - in all active forms of the suffix conjugation;

- the existence of two prefix conjugations (Akkadian, Modern South Arabian, Ethio-Semitic);

- the emergence of the -na ending (3pl.f, 2pl.f) in Central Semitic (cf. Hetzron 1976);

- the isogloss $p$ (Akkadian, Aramaic, Canaanite) vs. $f$ (Arabic, SouthArabian, Ethio-Semitic.

Representing the "traditional" criteria, Faber (1997) arrived at the following model (apud Huehnergard and Rubin 2011: 260): 


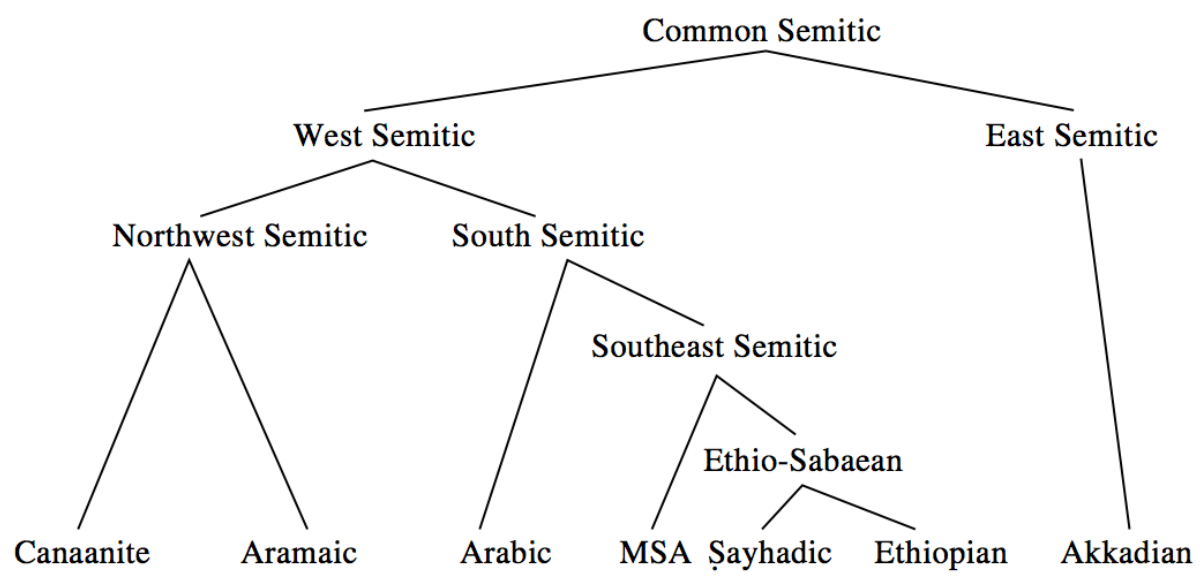

FIGURE 1: Stemma according to Faber 1997.

Hetzron (1976), to whom we owe the concept of "archaic heterogeneity" and "shared morpho-lexical innovations" in Semitic, had arrived at the following genealogical representation (apud Huehnergard and Rubin 2011: 262):

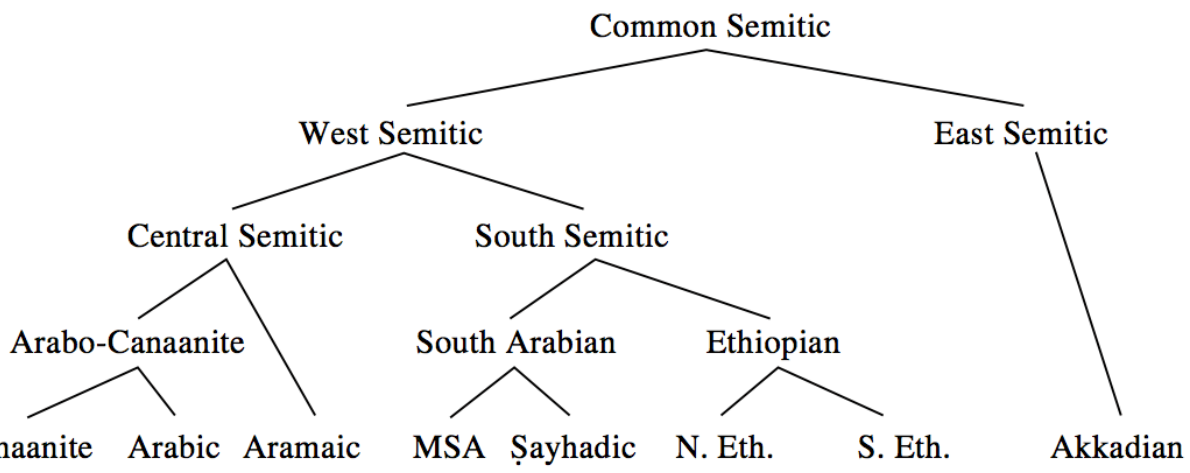

FIGURE 2: Stemma According to Huehnergard and Rubin 2011.

Porkhomovsky (1997) and others have since then refined the previous model as follows. It is noteworthy that both Modern South Arabian ("MSA") and EthioSemitic ("Ethiopian") branch off at a quite high level in this model (apud Huehnergard and Rubin 2011: 263): 


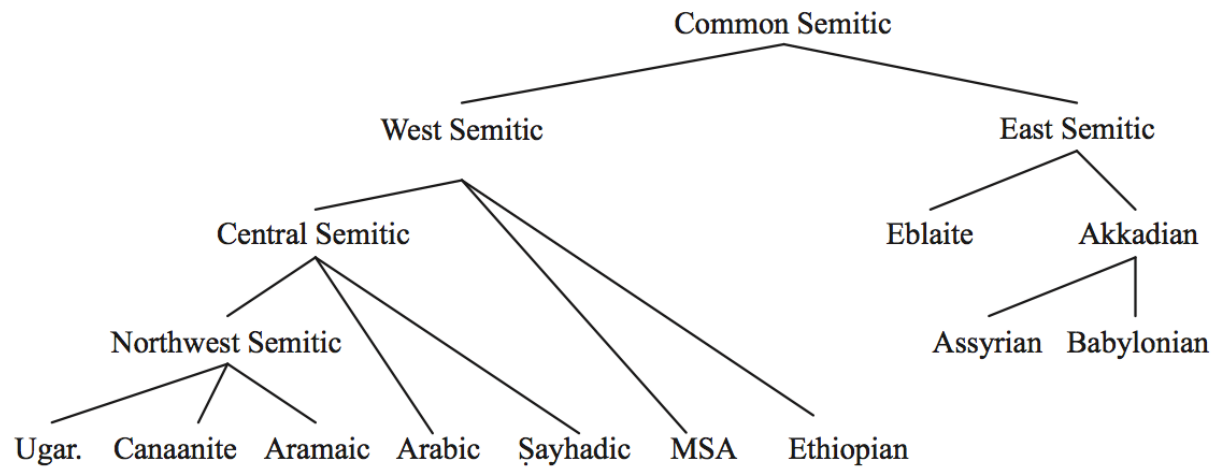

FIGURE 3: Stemma according to Porkhomovsky 1997.

Kogan (2015), who focuses entirely on the role of the lexicon, also ascribes quite early genealogical independence to both (modern) South Arabian and EthioSemitic. He arrives at the following model, curiously mirroring East and West in his representation (Kogan 2015: 600). The encircled language groups in Kogan's model can be interpreted as representing linguistic areas in which contact phenomena are especially relevant. In terms of the goals of this paper, Kogan's model underlines the linguistic distinctiveness of the South-Semitic area:

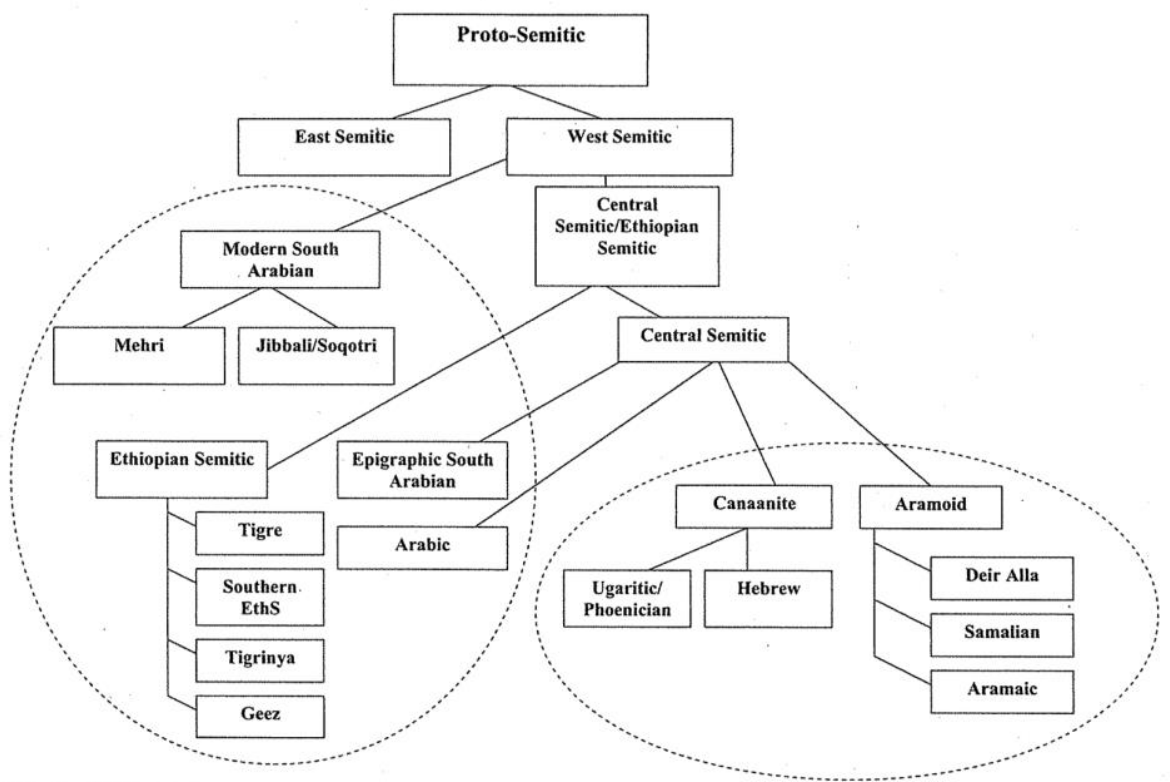

FIGURE 4: Stemma according to Kogan 2015. 


\section{[2] ISSUES OF LEXICAL CLASSIFICATION}

One aspect clearly affecting the lexical distinctiveness of Ethio-Semitic is the Cushitic substratum in Ethio-Semitic (cf. Leslau 1945, 1952; Appleyard 1977). Appleyard (1977) identifies Cushitic loans especially in the following semantic fields: "man", comprising general terms, kinship terms, and parts of the body; "the domestic environment", comprising agricultural activities and implements, crops, domestic animals, food and its preparation, and the [realm of the] house; "the natural environment", comprising natural phenomena, flora, and fauna; "social organization", comprising law and government, economy, warfare, and religion; and "grammatical items", comprising pronouns, numerals, and particles. In addition, the core Semitic stock of the Modern South Arabian and Ethio-Semitic vocabulary also displays specific semantic traits in its lexicon, traits that may be due to linguistic contact or may even reflect early retentions.

Before turning to look more closely at a selected sample of Ethio-Semitic data, here is a brief overview of some issues that have the potential to complicate lexical classification, keeping the Ethio-Semitic scenario in mind.

[2.1] Issues of choice of lemmata: lexical lists based on genetic cognates vs. lexical lists based on target language

Grosso modo, lexical lists can be based either on genetic cognates within a language family, irrespective of the precise meaning of the lexical items in the individual languages (e.g., Bergsträsser 1983: 210-223) or on lists of words with (approximately) the same meaning in a target language, which, however, need not be genetically related (e.g., Bennett 1998: 232-249). Kogan (2015) takes both strategies into consideration, but pays special attention to the second strategy, building his arguments on a kind of modified Swadesh list.

The lemma "sun" in Semitic may serve to illustrate the situation. While East and Central Semitic (and also Epigraphic South Arabian, "ESA") use the root $\checkmark$ š-m-s in variations, the modern South Arabian languages resort to the lemmata for "day" $(\sqrt{ } \mathrm{y}-\mathrm{w}-\mathrm{m})$ and "pre-noon" $(\sqrt{ } \mathrm{d}-\mathrm{h}-\mathrm{y})$ respectively, roots which are also attested in other branches of Semitic but constitute lexical innovations in the cited South Semitic branches. Here is an overview of the lemma "sun" in Semitic (cf. also Leslau 1987: 149):

The lemma "sun" in Semitic

Akkadian

Hebrew

Aramaic šamšum

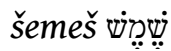

šemšā منrš 


\begin{tabular}{|c|c|}
\hline ESA & šms \\
\hline Arabic & شَams شْسْس \\
\hline Mehri & ḥə-yáwm (yum / šum) \\
\hline Ḥarsūsī & ḥe-yōm \\
\hline Jibbāli & yum \\
\hline Gə⿳亠口冋 & daḥ̄ay $\theta$ ch,e \\
\hline Amharic & șähay $\theta$ h,e \\
\hline Argobba & çähhed \\
\hline $\begin{array}{l}\text { Gurage } \\
\text { (cf. Arabic }\end{array}$ & $\begin{array}{l}\text { ç̣et } \\
\text { •"pre-noon" and Heb }\end{array}$ \\
\hline
\end{tabular}

\section{[2.2] Issues of diachronic inner-subgroup loan}

Diachronic loans within the same genetic subgroup (e.g., from Gə'əz to Amharic) can also create confusion in the realm of phonology. A well-known (probably universal) phenomenon is the fact that proper nouns (place names and personal names) tend to be phonologically (and orthographically) more conservative than correlating common nouns and verbs. Within Ethio-Semitic, one can observe that the phonological structure of nouns in Gə'əz containing gutturals is still preserved in loaned terms in Amharic (at least orthographically), whereas the gutturals are lost in the respective verbal forms belonging to the same root. Here is an example comprising four terms (cf. also Edzard 2015b: 189):

guttural retained

+qovcit tamhart

aDqith mäșhaf [mäșhaf]

S.' dähna [dä(h)na]

wó $s \partial^{\prime} \partial \mathrm{l}$ vs

'lesson'

'book'

'well'

'picture' +oqu tämari 'student

26. șafä 'he wrote'

. danä 'he recovered'

चत salä 'he painted'

\section{[2.3] Issues of inner-family loan}

An especially intricate issue is the distinction between genetically related cognates on the one hand and and inner-family loans on the other. The latter term refers to loan between languages of the same genetic subgroup, which may engender semantic specification of an indigenous term due to its interaction with a genetic cognate. In the case of the latter, usual lautgesetzlich correspondences need no longer obtain. Also the semantics need not be exactly maintained in the borrowing process. An example, featuring loans from Ga'az to Arabic, is the following (cf. Weninger 2007; Edzard 2015b: 187): 
Gə‘วz

Ффेक:

hnc kabaro

ongat: mașhaf

an'7nc. manbar 'chair, throne' > minbar 'pulpit' (no root $\sqrt{ } n-b-r$ 'to sit' in Arabic)

[2.4] Issues of autochthonous vocabulary vs. loaned vocabulary in target languages

Of special interest is the case where lexical doublets emerge as a result of inner-family borrowing. In this case, the respective lemma is both attested autochthonously and in a loaned version (cf. Edzard 2015a for a contextualization of this issue). Typically, the borrowed lemma then has a specialized meaning. While Arabic, for instance, features the autochthonous word $\theta \bar{a} b a$ 'he returned', one also finds the Aramaic loanword tāba 'he repented' (i.e. "returned" in a moral sense). Brockelmann had already examined this issue in his Grundriss (Brockelmann 1908-1913, vol. 1: 119). Examples are the following (cf. also Lonnet 2005; Tezel 2010; Leslau 1990):

\begin{tabular}{|c|c|c|c|c|c|}
\hline Arabic & bann $\bar{a}$ & $>$ & $\begin{array}{l}\text { Mehri } \\
\text { Mehri }\end{array}$ & $\begin{array}{l}\text { bannāy 'bricklayer' (loaned) } \\
\text { mannōy }\end{array}$ & vs \\
\hline \multirow[t]{2}{*}{ Aramaic } & tāb & $>$ & Arabic & $\begin{array}{l}\text { 'bricklayer' (autochthonous) } \\
\text { tāba 'he repented' (loaned) }\end{array}$ & vs \\
\hline & & & Arabic & $\begin{array}{l}\theta \bar{a} b a \text { 'he returned' } \\
\text { (autochthonous) }\end{array}$ & \\
\hline \multirow[t]{2}{*}{ Akkadian } & $\begin{array}{l}\text { ušesși } \\
\text { 'he sent out' }\end{array}$ & $>$ & Aramaic & šesși ' he accomplished' (loaned) & vs \\
\hline & & & Aramaic & $i^{c} \bar{a}$ 'he grew' (autochthonous) & \\
\hline Arabic $\sqrt{ }$ & ${ }^{3}-x-r$ & $>$ & $\begin{array}{l}\text { Ṭūrōyo } \\
\text { Ṭūrōyo }\end{array}$ & $\begin{array}{l}\text { m'āxar 'to be late' (loaned) } \\
\text { hrēno } \\
\text { '(an)other' (autochthonous) }\end{array}$ & vs \\
\hline \multirow[t]{2}{*}{ Arabic } & $\begin{array}{l}\text { madar } \\
\text { 'clouds of mud' }\end{array}$ & $>$ & Amharic & ox@C. mädär 'clay' (loaned) & vs \\
\hline & & & Amharic & $\begin{array}{l}\text { g.e.c. madar 'earth ground' (au- } \\
\text { tochthonous) }\end{array}$ & \\
\hline
\end{tabular}


[2.5] Issues of semantic innovations in Ethio-Semitic

First of all, the example of the lemma "sun" in Semitic has already been mentioned. Kogan (2015), who takes a modified version of the Swadesh list as a point of departure, points out the following further examples of semantic innovation in Ethio-Semitic (cf. Kogan 2015: 444-446):

V l-ḥ-ṣ 'to peel, bark'

Gə⿳亠口冖 ndo lahada

Amharic In lațä

Tigrinya n丸s lähaṣä

$\checkmark$ k-b-d 'liver, stomach, belly'

Gacaz nne: kabd

Amharic vP: hod (käbd > häbd > häwd > hod)

Tigrinya hrn.e. käbdi

$\checkmark$ m-d-r 'earth, ground, soil'

Gacaz qoece madr

Amharic qoe:c madar

Tigrinya q0.6 madri

$\checkmark$ b-l-c 'to eat, consume, devour'

Gə`əz naobal'a

Amharic nn bälla

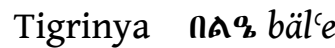

$\sqrt{ }$ d-h-y 'shine, sun'

Ga'az ox, dahāy

Amharic od,e dahāy [șähay] / m,e țay

Tigrinya os,e ḍahāy [șähay]

$\checkmark \mathrm{k}-\mathrm{l}-\mathrm{\prime}$ 'both, two'

Ga'az nas kal'e

Amharic v-n'hulätt

Tigrinya nat kalotte

[2.6] Ethiopian terms of uncertain origin (Swadesh list)

The etymological origin a of a given word cannot be determined with certainty 
in every case. Ethio-Semitic examples include the following (cf. Kogan 2015: 446-448):

$\checkmark$ hi-m-d 'ashes'

Ga'az hose. hamad

Amharic kose amäd

Tigrinya hose hamäd

$\checkmark$ q-ṣ-l 'leaf

Ga`az \$\&:a q aṣl

Amharic \$̇an qațäl

Tigrinya \$\&:n. $q^{w} \ddot{a ̣ s l i ~}$

$\sqrt{ } \mathrm{s}-\mathrm{b}_{-}$' 'man'

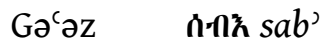

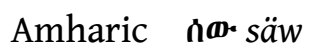

Tigrinya n-nk,e säb'ay

$\sqrt{ } \mathrm{q}-\mathrm{y}-\mathrm{h}$ 'red'

Ga'əz $\quad$ sed qayyah

Amharic $\boldsymbol{\phi} \boldsymbol{e}$ qäyy

Tigrinya \$eڤ qäyyzh

$\sqrt{ } \mathrm{m}-\mathrm{w}-\mathrm{q}$ 'warm'

Ga`az $\mathbf{q D} \boldsymbol{0} \cdot \dot{\phi}$ mawwaq

Amharic op. $\mathbf{\phi} m u q$

Tigrinya $\mathbf{q} \mathbf{p} \mathbf{\phi}$ moq

[2.7] Permutations

Cognate roots do not always appear in exactly the same order. The concept of "metathesis" is not meaningful in every case. Rather, at least in some cases, the semantics of a given term appear to be linked to the (non-ordered) set of the root consonants.

non-Ethiopic

Akkadian epēqum 'enclose'

Arabic falqata 'hurry'

Soqoțri ig'alil 'roll oneself'

Arabic jaraza/jazara 'tear, bite'

Arabic fahara/hafara 'dig, notch'
Gə`əz

क中6. haqafa 'hug, embrace, ...'

\$Amb. qaltafa 'hurry'

o1n 'agala 'place in layers, ...'

1८.H/7HL garaza/gazara 'cut, circumcise'

6.dhefahara 'dig (up), bury 


\section{[3] THREE SAMPLE ENTRIES}

In the following, four sample entries will considered: $\sqrt{ } n-f-s, \sqrt{ } d-b-r, \sqrt{ } r-k-b$, and $\sqrt{ }$ h-g-r, which shed light on the previously mentioned importance of South Arabian and Ethio-Semitic for classification.

\section{[3.1] $\sqrt{ } n-f-s$}

This root is attested across Semitic and is relatively straightforward in the distribution of its semantic range. As this root served as a model example within the Doha project, context is also provided in this case. For the semantic connection between "life" and "tomb", see also Steiner 2015.

\section{East Semitic}

Akkadian $\sqrt{ } n-p-s ̌ s$

- verb: napāšum 'to breathe freely, blow, relax, expand'

li-ip-pu-uš-ilum 'let him breathe, O God' (personal name)

- noun: napišum 'breath(ing)'

$\operatorname{napištu}(m)$ '(essence of) life; throat'

West Semitic

Central Semitic

Arabic $\sqrt{ } \mathrm{n}$-f-s

- verb: نَفُسنَ nafusa 'to be precious; نَفِسن nafisa 'to be parsimonious, envious'

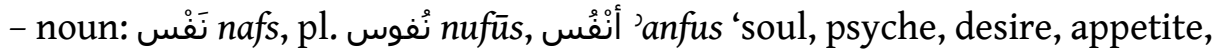
being, person, self'

نَفَس nafas, pl. أنْفاس 'anfās 'breath, sip'

Nabatean $\sqrt{ }$ n-f-s

nafs 'tomb'

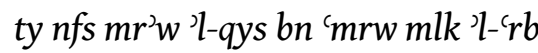

'This is the tomb of MR'LQYS, son of 'MRW, king of the 'RB'

(an-Namāra inscription; cf. Retsö 2003: 467-470)

Northwest Semitic

Ugaritic $\sqrt{ } \mathrm{n}-\mathrm{p}-\check{\mathrm{s}}$

$n p s ̌$ 'soul, (sexual) appetite'

'ap npš 'funerary document'

Phoenician $\sqrt{ } \mathrm{n}-\mathrm{p}-\check{s}$

npš I 'person, personnel, emotions' 
l-npšbt '̌s $l^{3}$-štt mkl '[paid] to the personnel of the temple of the consorts of MKL'

npš II 'funerary monument, tombstone'

$n^{\prime} p \check{s}^{\mathrm{s}} \mathrm{dyt}$ '[this the] funerary monument of Š'DYT'

Northwest Semitic in general (Phoenician, Punic, Moabite, Ammonite, ElAmarna; Nabatean, Palmyra, Hatra) $\sqrt{ } \mathrm{n}-\mathrm{p} / \mathrm{b}-\mathrm{s}$

npš I 'life'

$n p \check{s}-k[y]$ 'lqḥ 'I will take your life'

$n p / b \check{s}$ II 'person'

$w$-tb'h $n b s^{\prime}-k$ 'and you(r person) will seek'

$n p / b s ̌$ III 'soul'

w-tšty nbš pnmw 'and may the soul of PNMW drink'

$n p / b s ̌$ IV 'disposition'

$n p / b s ̌ V$ 'funerary monument'

Hebrew $\sqrt{ }$ n-p-š

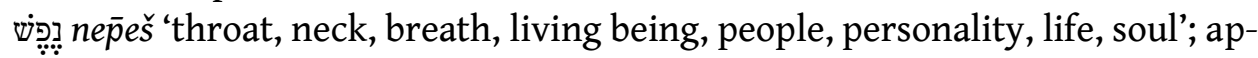
positional reflexive pronoun

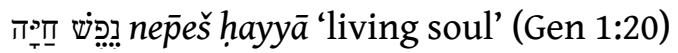

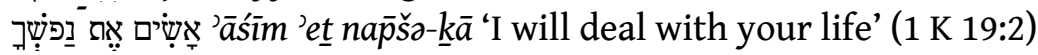

בְִּ

Aramaic

Babylonian Aramaic $\sqrt{ } \mathrm{n}-\mathrm{p}-\check{\mathrm{s}}$

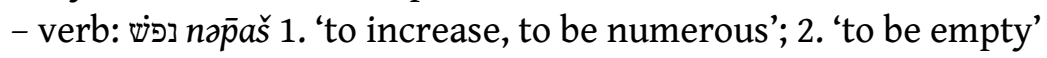

- noun:

Palestinian Aramaic $\sqrt{ }$ n-p-š

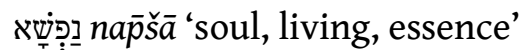

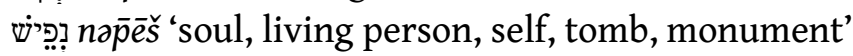

Syriac Aramaic $\sqrt{ } \mathrm{n}-\mathrm{p}-\mathrm{s}$

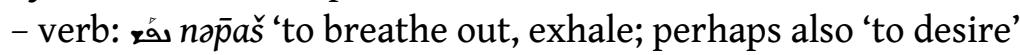

- noun: R'á nā̄ša 'breath of life, soul, person; funerary monument'; reflexive pronoun'

South Semitic

Eastern South Semitic 
Modern South Arabian (Mehri, Jibbāli, Ḥarsūsi, Soqoțri)

Mehri $\sqrt{ }$ n-f(-s)

- noun ḩว-nōf 'self'

- verb: anōfes 'to make space'; antəfūs 'to be safely delivered of a child'; šonfūs

'to welcome s.o.'

- noun: nafs/nəfáws 'individual, soul, person'

Jibbāli $\sqrt{ } \mathrm{n}-\mathrm{f}$

núf'self'

Harsūsi $\sqrt{ } \mathrm{n}-\mathrm{f}$

- noun he-nōf/he-nyehōf 'self'

Soqoțri $\sqrt{ } \mathrm{n}-\mathrm{h}-\mathrm{f}\left(\mathrm{h}=\mathrm{s} / \mathrm{s}\right.$; metathesis of $\mathrm{C}_{2}$ and $\left.\mathrm{C}_{3}\right)$

nhof 'soul'

Regarding the importance of South Semitic, Kogan (2015: 578) remarks: "The MSA terms with the meaning "self" are hard to separate from PS *napš- (note especially the plural nốfoš in Soqotri), but Jib. núf makes it clear that the ProtoMSA form should be reconstructed without $*_{s}$-, which does not shift to $h$ and cannot be dropped in Jibbali (cf. SED I [= Militarev and Kogan 2000, LE] No. 46 v and $\left.51_{v}\right)$."

Western South Semitic

Epigraphic/Old South Arabian (mainly Sabaic) $\sqrt{ } \mathrm{n}-\mathrm{f}-\mathrm{s}$

- verb: $h \mathrm{~s}_{1}$ (assimilated $n$ ) 'to open up (water channel)'

- noun:

$n f s_{1}$ I 'soul, person, self, life'

$n f s_{1}$ II 'funerary monument'

$n f s_{1}$ III 'woman in childbed'

Ethiopian Semitic

North Ethiopic

Gə`əz $\sqrt{ }$ n-f-s

- verb: '\$: nafsa 'to blow (wind, spirit)'

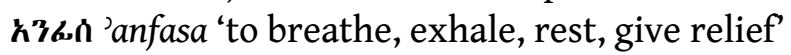

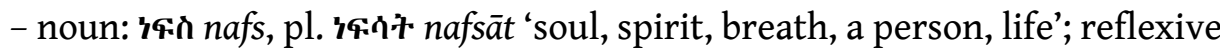
pronoun

'F:A' nafsāt 'body, genitals' 
South Ethiopic

Amharic $\sqrt{ }$ n-f-s

- verb: '16.đ näffäsä 'to blow (wind, spirit)'

†'ı.র tänäffäsä 'breathe'

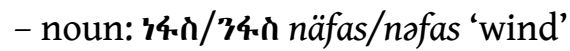

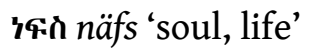

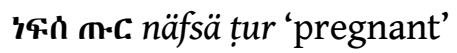

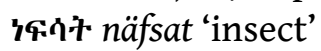

$$
\sqrt{ } d-b-r
$$

This root has a wider semantic range. Indeed, in the case of this root we are probably looking at a variety of different homophonic lexical entries. EthioSemitic presents the additional semantic aspect of "monastery", i.e. something lying on the back of a mountain. In Mehri and Amharic, one can observe interesting cases of metathesis.

East Semitic

Akkadian $\sqrt{ } \mathrm{d}-\mathrm{b}-\mathrm{r}$

- verb: dupurrum 'to depart, recede'

- noun: madbaru, mud(a)baru 'steppe, desert'

dibiru 'mischief'

dubur 'fundament'

West Semitic

Central Semitic

Arabic $\sqrt{ } \mathrm{d}-\mathrm{b}-\mathrm{r}$

- verb: دَبَرَ dabara 'turn one's back, elapse'

dabbara 'make arrangements'

- noun: دُبرَ دubr 'rump, backside'

dabra 'turn (of fate)'

dabūr 'west wind'

dabbūr 'hornet, wasp'

Northwest Semitic

Ugarit $\sqrt{ } \mathrm{d}-\mathrm{b}-\mathrm{r}$

- verb: dbr 1. 'drive away'; 2. 'to say, declare'

- noun: dbr 'matter, thing'

$d b r$ 'plague, pestilence' 
Phoenician $\sqrt{ } \mathrm{d}-\mathrm{b}-\mathrm{r}$

- verb: $d b r$ 'to say'

- noun: dbr 1. 'thing, matter, act' 2. 'word, promise'; 3. 'pl. affairs, acts, history';

4. 'statement, declaration'

Hebrew $\sqrt{ }$ d-b-r

- verb: 꼬ำ

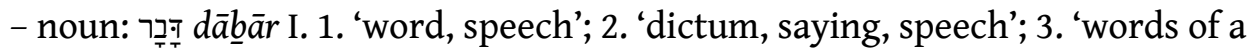
poet'; 4. 'God's words to the prophets'; 5. 'promise'; 6. 'assignment'; 7. 'wish';

8. 'suggestion'; 9. 'message'; 10. 'appointment'

II. 1. 'thing'; 2. 'incident'; 3. 'doing, business, traffic'; 4. 'matter'; 5. 'portion' dege derer 'cattle plague'

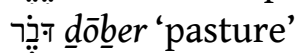

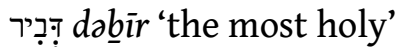

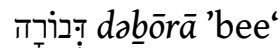

\section{Aramaic}

Babylonian / Palestinian Aramaic $\sqrt{ } \mathrm{d}-\mathrm{b}-\mathrm{r}$

- verb: דבר dbr 'to take, act'

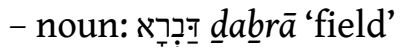

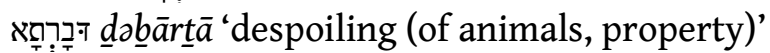

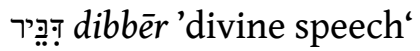

Syriac Aramaic $\sqrt{ } \mathrm{d}-\mathrm{b}-\mathrm{r}$

- verb: is dabar 1. 'to lead, guide, drive, take with oneself, to merry, pass of time'; 2. 'to move, bestir, depart, ride a horse, wander, go back, return'

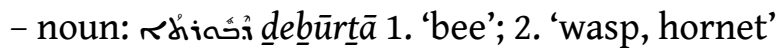

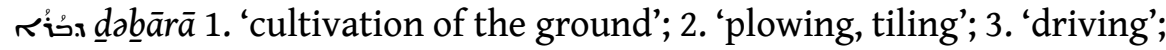

4. movement, agitation'

Кำ dabrāā 1. 'land, field'; 2. 'desert'; 3. 'pasture land'

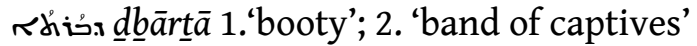

South Semitic

Eastern South Semitic

Modern South Arabian

Mehri $\sqrt{ }$ d-b-r

- verb: adōbar 'to turn the back'

dábar 'to think, reflect'

$\sqrt{ } \mathrm{r}-\mathrm{d}-\mathrm{b}$ 
- noun: 'ardyīb/'ardyōb 'nape of the neck and the top of the shoulders'

Ḥarsūsi $\sqrt{ }$ d-b-r

- verb: ādēber 'to turn away (from)'

Soqoțri $\sqrt{ }$ d-b-r

- noun: 'ídbeher 'bee'

$\sqrt{ } \mathrm{r}-\mathrm{d}-\mathrm{b}$

- noun: 'ardib 'nape of the neck and top of the shoulders'

Western South Semitic

Epigraphic/Old South Arabian

Sabaic $\sqrt{ }$ d-b-r

- noun: $d b r$ 'payment in the form of work (?)'

Ethiopian Semitic

North Ethiopic

Gə`az $\sqrt{ }$ d-b-r

- verb: +.en tadabbara 'to lie on one's back'

Pnc dabara 'establish a monastery'

enco dabrawa 'be well-developed, be well-grown (child), engage in illicit sex'

- noun: $\boldsymbol{\rho} \cdot n c$ dabr 'mountain, region where there is a monastery, convent, monastery'

:nc : e.nc dābar, dabr 'territory, city, village'

:10.c : 'in.c. dāber, dābir 'shrine, sanctuary, innermost room, ecclesiastic council'

South Ethiopic

Amharic $\sqrt{ }$ d-b-r

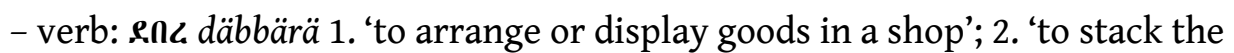
packed merchandise to form a sort of shelter (merchant when setting up camp for the night)'; 3. 'to raise the rank of a church to däbr (main church which provides sanctuary to individuals seeking refuge from persecution or prosecution)'; 4. 'to delimit the sacred confines of a church'; 5. 'to pile, stack, heap up, to put in a row or line'

\&n däbbärä 1. 'to be chubby, to thrive (baby); 2. 'to mature, reach full maturity, grow to full size'

- noun: enc däbr, däbar 'main church (one of high status which is surrounded by a sacred grove, endowed with ample lands [until 1975] and served by many däbtära-cantors)' 
Snc dabre 1. 'a large pottery vessel, crock, ewer'; 2. ' pet name a peasant gives to the ox that tramples the grain'

$\sqrt{\mathrm{g}}-\mathrm{r}-\mathrm{b}$

- noun: ‘ccq/ 'rca ğärba, žärba 1. 'back (part of the body), loins'; 2. 'carcass of a chicken'; 3. 'reverse (of a coin)'; 4. 'the underside of the onğärä, i.e. the part that lies against the griddle'; 5. 'rear (back)'; 6. 'behind (prep.)'

\section{[3.2] $\sqrt{ } r-k-b$}

The third sample root is again relatively straightforward, with equally broad attestation across Semitic, but features the additional semantic aspect of "taking possession" in Ethio-Semitic.

\section{East Semitic}

Akkadian $\sqrt{ } \mathrm{r}-\mathrm{k}-\mathrm{b}$

- verb: rakābum 1. 'to mount, ride on (chariot, boat, animal; of gods 'ride' wind, storm etc.)', 2. 'mount (sexually) of animal, man'; 3. 'to be superimposed (of moon 'cover, eclipse' star)'; 4. 'of plough share (šinnum) to cut furrow'

West Semitic

Central Semitic

Arabic $\sqrt{ } \mathrm{r}-\mathrm{k}-\mathrm{b}$

- verb: رَكَكِ rakiba 'ride, mount (an animal), travel'

- noun: رَكْبَ rakb 'riders, horsemen'

مَرْكب markab 'ship, vessel'

Northwest Semitic

Ugarit $\sqrt{ } \mathrm{r}-\mathrm{k}-\mathrm{b}$

- verb: $r k b$ 'to mount (especially a chariot)'

- noun: $r k b$ 'charioteer, (epithet of the god $B^{c} L$ )'

Hebrew $\sqrt{ } \mathrm{r}-\mathrm{k}-\mathrm{b}$

- verb: רָָָ rākab 1. 'ride'; 2. 'drive'; 3. 'to get on, mount'

- noun: רֶֶֶ reke $\underline{b}$ 1. 'convoy'; 2. 'train'; 3. 'wagon, chariot'; 4. the upper grinding stone of a hand mill'

בฺָָָ rakkāb 1. 'rider'; 2. 'charioteer'

Aramaic

Babylonian / Palestinian Aramaic $\sqrt{ } \mathrm{r}-\mathrm{k}-\mathrm{b}$

- verb: רכב rkb 1. 'to ride, mount': 2. 'to impose upon so.'; 3. 'to copulate (of animals)' 


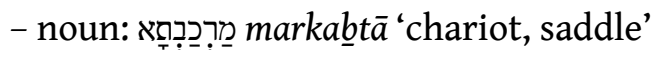

רכו rkb 1. 'rider'; 2. 'upper millstone'

Syriac Aramaic $\sqrt{ } \mathrm{r}-\mathrm{k}-\mathrm{b}$

- verb: حَi rokeb 1. 'to mount, bestride, ride a horse, mule, camel'; 2. 'to cover in breeding'

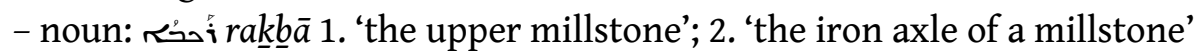

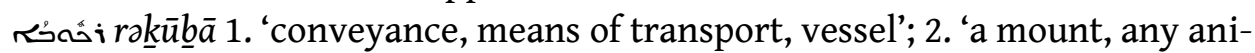
mal for riding, horse'; 3. 'riding, horsemanship'

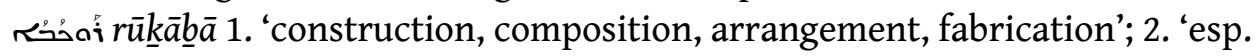
the compounding of medicines, a recipe'; 3. 'structure of the body'; 4. 'literary composition'

South Semitic

Eastern South Semitic

Modern South Arabian

Mehri $\sqrt{ } \mathrm{r}-\mathrm{k}-\mathrm{b}$

- verb: rēbab 'to ride'; 2 . 'to mount'; 3. 'to sleep with a woman'

$a r \bar{k}$ ab 'to put (a pot) on the fire'

$r t z k \bar{u} b$ 'to get on to the right road and go straight along it'

- noun: rakb 'ledge on a cliff (of about the size one could sleep on)'

rōkab 'rider

markēb/ maráwkəb 'boat'

Jibbāli $\sqrt{ } \mathrm{r}-\mathrm{k}-\mathrm{b}$

- verb: rékab 'to ride, mount (also with a sexual connotation)'

erókub 'to put (a pot) on the fire'

rótkab 1. 'to jump on one another (in play or sexual intercourse)'; 2. 'to commit an offence'

- noun: crkíb, yurs̃ób 'riding-camel'

rókub 'rider'

merkéb/mirébkəb 'boat'

Ḥarsūsi $\sqrt{ } \mathrm{r}-\mathrm{k}-\mathrm{b}$

- verb: rēkeb 'to mount, ride'

arēkeb 'to put food in a pot to cook over the fire'

- noun: rékbi 'horseman'

rekib 'riding camels'

márkeb 'ship' 
merkebét 'saddle-sore'

Soqoțri $\sqrt{ } \mathrm{r}-\mathrm{k}-\mathrm{b}$

- verb: rékob (ríkub) 'to mount'

- noun: rékkeb 'knight'

márkeb 'boat'

Western South Semitic

Epigraphic/old South Arabian

Sabaic $\sqrt{ }$ r-k-b

- verb: $r k b$ 'to ride a horse'

- noun: rkb 1. 'rider, specifically cameleer'; 2. 'camelry'; 3. coll. 'riding animals'

Ethiopian Semitic

North Ethiopic

Gəcoz $\sqrt{ } \mathrm{r}-\mathrm{k}-\mathrm{b}$

- verb: Lhn rakaba 1. 'find, get, acquire, obtain, attain, receive, gain, reach, take possession of, possess, overtake, apprehend, invent, find out, discover, perceive, suppose'; 2 . 'come upon, fall upon, befall, occur, come to pass, happen, be becoming to, be proper'

- noun: chn-n't rakubāt 'beings'

Ln-n rakb 'congregation, meeting, council, assembly'

«hn rukābe 'joining together, intercourse'

chn't rakbat 'discovery, finding, acquisition, existence'

South Ethiopic

Amharic $\sqrt{ } \mathrm{r}-\mathrm{k}-\mathrm{b}$

- verb: Lhn, + Lhn räkäbä, täräkkäbä 'take over (a business), take possession, be turned over (weapons)

'hnıhn 'asräkkäbä 'deliver (merchandise), turn over (weapons), surrender

(arms), hand in, hand over'

- noun: 'cch'n 'arkab 'sirup'

\section{[3.3] $\sqrt{ } h-g-r$}

This root is primarily attested in South Semitic. Leslau (1991: 216) does not relate the South Semitic meaning "city, land" to the concept "migration", as attested in Arabic, South Arabian, and Ethio-Semitic.

West Semitic

Central Semitic 
Arabic $\sqrt{ } \mathrm{h}-\breve{g}-\mathrm{r}$

هاجَرَ hāğara 'emigrate'

هiğra 'emigration'

Hebrew $\sqrt{ }$ h-g-r

Ṭִ higgèr 'emigrate', immigrate'

PN: דָָָר̄ $h \bar{a} \bar{a} r$ 'Hagar, Egyptian slave and concubine'

South Semitic

Eastern South Semitic

Modern South Arabian

Mehri $\sqrt{ }$ h-g-r

- verb: hagūr 'to buy food for one's family'

hōgar 1 . 'to leave your family and emigrate'; 2 . 'to travel at midday, between 11 and 3 o'clock'

hègar 'to be hot at midday'

Jibbāli $\sqrt{ }$ h-g-r

- verb: hógór 'to (leave o's family and) emigrate'

ohógur 'to come, go at midday (between 11 and 3 o'clock)'

- noun: hogar 'midday'

Western South Semitic

Epigraphic/old South Arabian

Sabaic $\sqrt{ }$ h-g-r

- noun: hgr 1. 'town, city - administrative center of a $s^{c} b$ (group of clans)';

2. 'settled territory'

hgrhmw 'town-dwellers'

Ethiopian Semitic

North Ethiopic

Gacoz $\sqrt{ }$ h-g-r

- noun: v1c: 'city, town, village, province, district, country, homeland, inhabited, region'

South Semitic

Amharic $\sqrt{\varnothing-g-r}$

- noun: ^lc: agär 'country, nation, territory, (region, land), district, state, land (country, fatherland)' 


\section{[4] CONCLUSION}

Even this short glimpse at the South Semitic (South Arabian and Ethio-Semitic) lexicon is revealing and rewarding. Clearly, South Arabian often features different or at least additional semantic traits in the lexicon. A systematic evaluation of sources such as Cohen 1970 - as well as the Semitic dictionaries with comparative evidence (notably Leslau 1987), will certainly bring to light more interesting material. The usefulness of lexicostatistics for genetic classification continues to be a point of discussion.

\section{AC KNOWLEDGMENTS}

I would like to thank the NORHED project - Linguistic Capacity Building - tools for inclusive development of Ethiopia and the editors of this book. I also appreciate the comments and suggestions made by my two anonymous reviewers.

\section{REFERENCES}

AHw = Soden, Wolfram von. 1972-1985. Akkadisches Handwörterbuch. 3 vols. Wiesbaden: Harrassowitz.

Appleyard, David. 1977. A comparative approach to the Amharic lexicon. Afroasiatic Linguistics 5. 1-67.

Beeston, Alfred F.L, M.A. Ghul, Walter W. Müller, and Jacques Ryckmans. 1982. Sabaic Dictionary / Dictionnaire sabéen / al-Mu'ğam as-Saba'ì. Louvain-la-Neuve: Peeters.

Bennett, Patrick. 1998. Comparative Semitic Linguistics. Winona Lake: Eisenbrauns.

Bergsträsser, Gotthelf 1983. Introduction to the Semitic Languages. Text Specimens and Grammatical Sketches. Translated with Notes and Bibliography and an Appendix on the Scripts by Peter D. Daniels, Winona Lake, Eisenbrauns.

Black, Jeremy, Andrew George, and Nicholas Postgate. 2000 ( $2^{\text {nd }}$ corr. print). A Concise Dictionary of Akkadian. Wiesbaden: Harrassowitz.

Brockelmann, Carl. 1908-1903. Grundriß der vergleichenden Grammatik der semitischen Sprachen. II. Band: Syntax. Berlin: Verlag von Reuther \& Reichard.

Biella, Joan Copeland. 1982. Dictionary of Old South Arabic. Sabaean dialect. Winona Lake: Eisenbrauns. 
CAD = Roth, Martha T. (ed.). 1956-2010. The Assyrian Dictionary of the Oriental Institute of the University of Chicago. Chicago: Oriental Institute.

Cohen, David, François Bron, and Antoine Lonnet. 1970 -. Dictionnaire des racines sémitiques ou attestées dans les langues sémitiques. Louvain: Peeters.

del Olmo Lete, Gregorio and Joaquín Sanmartín. 2003. A Dictionary of the Ugaritic Language in the Alphabetic Tradition. Leiden: Brill.

Edzard, Lutz 2011. Die SIG.ALAN = Nabnitu-Liste und das Konzept der semitischen Wurzel. Zeitschrift der Deutschen Morgenländischen Gesellschaft 161(1). 17-37.

Edzard, Lutz. 2012. Introduction: Semitic and Afroasiatic. In Lutz Edzard (ed.), Semitic and Afroasiatic: Challenges and opportunities, 23-58. Wiesbaden: Harrassowitz.

Edzard, Lutz. 2015a. Zum Verhältnis von Lehnbildung und genetischer Verwandtschaft im Semitischen. In Viktor Golinets, Hanna Jenni, HansPeter Mathys, and Samuel Sarasin (eds.), Neue Beiträge zur Semitistik. Fünftes Treffen der Arbeitsgemeinschaft Semitistik in der Deutschen Morgenländischen Gesellschaft vom 15. - 17. Februar 2012 an der Universität Basel, 19-33. Münster: Ugarit-Verlag.

Edzard, Lutz. 2015b. Inner-Semitic loans and lexical doublets vs. lexical doublets vs. genetically related cognates. In Aaron Butts (ed.), Semitic Languages in Contact, 181-197. Leiden: Brill.

Faber, Alice. 1997. Genetic subgrouping of the Semitic languages. In: Robert Hetzron (ed.), The Semitic Languages, 3-15. London: Routledge.

Gesenius = Donner, Herbert (ed.). 1987-2012. Wilhelm Gesenius' Hebräisches und Aramäisches Handwörterbuch über das Alte Testament. 18th ed. Berlin: Springer Verlag.

Goldenberg, Gideon. 2013. Semitic Languages. Features, Structures, Relations, Processes. Oxford: Oxford University Press.

Hetzron, Robert. 1976. Two principles of genetic reconstruction. Lingua 38. 89104.

Hoftijzer, Jacob and Karel Jongeling. 1995. Dictionary of the North-West Semitic Inscriptions. 2 vols. Leiden: Brill. 
Huehnergard, John and Aaron D. Rubin. 2011. Phyla and waves: models of classification of the Semitic languages. In Stefan Weninger (ed.), The Semitic Languages, 259-278. Berlin: de Gruyter.

Johnstone, Thomas M. 1977. Harsūsi Lexicon and English-Harsūsi Word-List. London: Oxford University Press.

Johnstone, Thomas M. 1981. Jibbāli Lexicon. Oxford: Oxford University Press.

Johnstone, Thomas M. 1987. Mehri Lexicon and English-Mehri Word-List: with index of the English definitions in the Jibbāli lexicon. London: School of Oriental and African Studies.

Kane, Thomas Leiper. 1990. Amharic-English Dictionary. Wiesbaden: Harrassowitz.

Kane, Thomas Leiper. 2000. Tigrinya Dictionary. Springfield: Dunwoody Press.

Koehler, Ludwig and Walter Baumgartner. 1994. The Hebrew and Aramaic Lexicon of the Old Testament, subsequently revised by Walter Baumgartner and Johann Jakob Stamm, translated and edited under the supervision of M.E.J. Richardson. Leiden: Brill.

Kogan, Leonid. 2015. Genealogical Classification of Semitic. The Lexical Isoglosses. Boston/Berlin: Walter de Gruyter.Leslau, Wolf. 1938. Lexique Soqotri (Sudarabique moderne) avec comparaisons et explications étymologiques. Paris: Librairie C. Klincksieck.

Krahmalkov, Charles R. 2000. Phoenician-Punic Dictionary. Leuven: Uitgeverij Peeters.

Leslau, Wolf. 1945. The influence of Cushitic on the Semitic languages of Ethiopia. A problem of substratum. Word 1(1). 59-82.

Leslau, Wolf. 1952. The influence of Sidamo on the Ethiopic languages of Gurage. Language 28(1). 63-81.

Leslau, Wolf. 1958. Ethiopic and South Arabic Contributions to the Hebrew Lexicon. Wiesbaden: Harrassowitz

Leslau, Wolf. 1969. Hebrew Cognates in Amharic. Wiesbaden: Harrassowitz.

Leslau, Wolf. 1976. Concise Amharic Dictionary. Wiesbaden: Harrassowitz.

Leslau, Wolf. 1987. Comparative Dictionary of Ge'ez (Classical Ethiopic). Wiesbaden: 


\section{Harrassowitz.}

Leslau, Wolf. 1990. Arabic Loanwords in Ethiopian Semitic. Wiesbaden: Harrassowitz.

Leslau, Wolf. 1976. Concise Amharic Dictionary. Wiesbaden: Harrassowitz.

Leslau, Wolf. 1987. Comparative Dictionary of Ge'ez (Classical Ethiopic). Wiesbaden: Harrassowitz.

Lonnet, Antoine. 2005. Emprunts intra-sémitiques: l'exemple des emprunts arabes en sudarabique moderne oriental. Aula Orientalis 26. 118-134.

Militarev, Alexander and Leonid Kogan. 2000. Semitic Etymological Dictionary. Vol I. Anatomy of Man and Animals. Münster: Ugarit-Verlag.

Militarev, Alexander and Leonid Kogan. 2005. Semitic Etymological Dictionary. Vol II. Animal Names. Münster: Ugarit-Verlag.

Nakano, Aki'o. 1986. Comparative Vocabulary of Southern Arabic. Tokyo: Institute for the Study of Languages and Cultures of Asia and Africa.

Payne Smith, J(essie). (ed.). 1903. A Compendious Syriac Dictionary Founded upon the Thesaurus Syriacus of R(obert) Payne Smith, D.D. Oxford: Clarendon Press.

Porkhomovsky, Viktor. 1997. Modern South Arabian languages from a Semitic and Hamito-Semitic perspective. Proceedings of the Seminar for Arabian Studies 27. 219-223.

Retsö, Jan. 2003. The Arabs in Antiquity. Their History from the Assyrians to the Umayyads. London/New York: Routledge/Curzon.

Retsö, Jan. 2006. Aramaic/Syriac loanwords. In: Kees Versteegh (ed.), Encyclopedia of Arabic Language and Linguistics, Volume I. A-Ed, 178-182. Leiden: Brill.

Rubin, Aaron D. 2010. The Mehri Language of Oman. Leiden: Brill.

Rubin, Aaron D. 2014. The Jibbali (Shahri) Language of Oman. Leiden: Brill.

Simeone-Senelle, Marie-Claude. 1997. The Modern South Arabian Languages. In Robert Hetzron (ed.), The Semitic Languages, 378-423. London: Routledge.

Simeone-Senelle, Marie-Claude. 2011. Modern South Arabian. In Stefan Weninger (ed.), The Semitic Languages. An International Handbook, 1073-1173. Berlin/Boston: Mouton de Gruyter. 
Sokoloff, Michael. 2002a. A Dictionary of Jewish Babylonian Aramaic of the Talmudic and Geonic Periods (= Dictionaries of Talmud, Midrash and Targum vol. 3). Ramat Gan: Bar Ilan University.

Sokoloff, Michael. 2002b (2nd ed.). A Dictionary of Jewish Palestinian Aramaic of the Byzantine Period (= Dictionaries of Talmud, Midrash and Targum vol. 2). Ramat Gan: Bar Ilan University.

Sokoloff, Michael. 2009. A Syriac Lexicon. A Translation from the Latin, Correction, Expansion, and Update of C. Brockelmann's Lexicon Syriacum.

Steiner, Richard. 2015. Disembodied Souls: The Nefesh in Israel and Kindred Spirits in the Ancient Near East, with an Appendix on the Katumuwa Inscription. Atlanta: SBL Press.

Tezel, Sina. 2011. Arabic Borrowings in Șūrayt/Ṭūrōyo within the Framework of Phonological Correspondences: in comparison with other Semitic languages. Uppsala: University Press.

Watson, Janet. 2012. The Structure of Mehri. Wiesbaden: Harrassowitz.

Weninger, Stefan. 2007. Ethiopic loanwords. In Kees Versteegh (ed.), Encyclopedia of Arabic Language and Linguistics, Volume II. Eg-Lan, 56-57. Leiden: Brill.

Winona Lake. 2009. Eisenbrauns / Indiana \& Piscataway, New Jersey: Gorgias Press.

Zaborski, Andrzej. 2003. Arabic loan-words. In Siegbert Uhlig et al (eds.), Encyclopaedia Aethiopica, vol. 1. A-C, 308-309. Wiesbaden: Harrassowitz.

\section{CONTACT}

\section{Lutz Edzard}

University of Oslo, Department of Culture Studies and Oriental Languages Universität Erlangen-Nürnberg, Institute for Near Eastern and East Asian Languages and Civilizations

l.e.edzard@ikos.uio.no 